\title{
IN VITRO ANTIMICROBIAL ACTIVITY OF MEXICAN PLANTS ON BOVINE MASTITIS BACTERIA: PRELIMINARY STUDIES
}

\author{
ATIVIDADE ANTIMICROBIANA IN VITRO DE PLANTAS MEXICANAS SOBRE \\ BACTERIAS DE MASTITE BOVINA: ESTUDOS PRELIMINARES
}

\author{
Mariana MACÍAS ALONSO $^{{ }^{*}}$; Julio C. LÓPEZ SALAZAR ${ }^{2}$; Soraya OSEGUEDA ROBLES ${ }^{1}$; \\ Iván CÓRDOVA GUERRERO ${ }^{3}$; Fernanda LEDEZMA GARCÍA ${ }^{1}$; Joaquín G. MARRERO ${ }^{\text {* }^{*}}$ \\ 1. Instituto Politécnico Nacional, UPIIG, Guanajuato, México; 2. La Casa del Bosque A.C. Guanajuato, México; 3. Facultad de Ciencias \\ Químicas e Ing. Universidad Autónoma de Baja California, México.*Corresponding author: mmacias@ipn.mx,jgonzalezm@ipn.mx.
}

\begin{abstract}
The present study aimed to evaluate the efficacy of traditionally used antibacterial plants (Euphorbia prostrata, Schinus molle, Brickellia veronicaefolia and Lepidium virginicum) in Santa Rosa Range in Guanajuato against major mastitis-causing pathogens. The selected plants were phytochemically screened for alkaloids, flavonoids, polyphenols, saponins, anthraquinone, cardiac glycosides, steroids and terpenoids. Moreover, to achieve the main purpose of the present research, extracts of selected plants were tested for in vitro antibacterial activity against Staphylococcus aureus, Escherichia coli, Shigella spp., Bacillus subtilis, Clavibacter spp., Proteus vulgaris and Salmonella spp. All these bacterial were isolated from clinical mastitis in dairy cows. The results indicated that the ethanolic extract of the aerial part of L. virginicum exhibited the strongest antimicrobial activity, and it could be potential candidate specie for the development of novel veterinary drugs with low cost and fewer side effects.
\end{abstract}

KEYWORDS: Antibiotic. Ethnomedicines. Dairy animals. Infectious disease. Mastitis.

\section{INTRODUCTION}

Bovine mastitis, an inflammation of the mammary gland caused by bacterial infection, is a highly prevalent disease in dairy cattle characterized by physical, chemical and usually bacteriological changes in milk and by pathological changes in the glandular tissues (LEBLANC et al., 2006). It is considered to be one of the most important diseases affecting the world's dairy industry (WELLENBERG et al., 2002). Mastitis is a complex disease caused by a variety of bacterial pathogens, mainly $S$. aureus and $S$. agalactiae (GOMES; HENRIQUES, 2016).

Current mastitis treatment, based on different intramammary antibiotic treatments, is very inefficient, because many bacteria are resistant to them (ZAFALON et al., 2007). Moreover, drug residues in milk have a potential health hazard effects for the consumer and may cause allergic reactions, interference in the intestinal flora and the rapid emergence of resistant bacteria (SAINI et al., 2012). For these reasons, this problem continues to deserve the attention of researchers and general population.

If we consider that approximately two-thirds of clinically used antibacterial therapies are derived from natural products, plant extracts could be an alternative for antibiotic agents (FARHA; BROWN, 2016). Alternative treatments to bovine mastitis with bacteriocins (PIETERSE et al., 2010) and plant derived compounds (BASKARAN et al., 2009; MUBARACK et al., 2011) have been described. For example, PHYTO-MAST® is a botanical preparation used for the intramammary treatment of clinical mastitis on organic dairy farm and demonstrated with good therapeutic effect (PINEDO et al., 2013).

Although ethnobotanical knowledge in human health have been widely reported in Mexico (SHARMA et al., 2017), the application of medicinal plants to veterinary medicine is poorly described. We believe that traditional medicine based on phytotherapy may complement and offer alternatives for animal disease control, especially in the search for new drugs antibiotics. For this reason, the main scope of the present study was to collect the knowledge of a rural community from Guanajuato State on the medicinal plants and herbal remedies used to treat infectious diseases, and evaluate the in vitro activity of extracts from selected plants against several gram positive and gram negative bacterial strains isolated from milk of cows with mastitis. To the authors' knowledge, this is the first study to establish the possible application of these plants into the veterinary 
phytotherapy. Thus, this research will provide scientific validation to traditional knowledge helping to develop novel veterinary drugs. In this sense, the present study aimed to evaluate the efficacy of traditionally used antibacterial plants (Euphorbia prostrata, Schinus molle, Brickellia veronicaefolia and Lepidium virginicum) in Santa Rosa Range in Guanajuato against major mastitis-causing pathogens.

\section{MATERIAL AND METHODS}

\section{Collection of information and plant samples}

This study was conducted in local communities located in Santa Rosa Range in Guanajuato State, Mexico, situated between 20 45'$21^{\circ} 25^{\prime} \mathrm{N}$ latitude and between $100^{\circ} 53^{\prime}-101^{\circ} 25^{\prime} \mathrm{O}$ longitude. Data collection was done using semistructured interviews and discussions with selected informants according to Bieski et al. (2015). The interviews took place between the period of July and December 2016. A free list method was used, which consisted of asking the informants to list the medicinal plants they knew and/or had used, the mode of preparation, the part used, the dosage and duration of treatment. Among all the documented plants only four highly used plants (Euphorbia prostrata, Schinus molle, Brickellia veronicaefolia and Lepidium virginicum) were selected for further in vitro screening. Additional ethnomedicinal, phytochemical and pharmacological information of these species was collected from a systematic literature review using different databases such as EMBASE, MEDLINE, PubChem, PubMed, SciELO, Science Direct and Scopus, using the search terms "Euphorbia prostrata", "Schinus mole", "Brickellia veronicaefolia", "Lepidium virginicum" "medicinal plant", "traditional uses", "praditional Medicine" and "ethnobotany", independently or in combination.

To evaluate the relative importance of the plant species based on its relative use among informants we used the use value (UV) index:

$$
U V_{i}=\Sigma U_{i} / n s
$$

where $U_{i}$ is the sum of the total number of use reports by all informants for a given species $\mathrm{i}$, and ns is the total number of informants. A high UV indicates that the plant is important, and a low UV suggests few reports are related to its use.

Plant materials collected during the study were washed under running tap water, rinsed in distilled water, dried in shade for 2 days and grinded to fine powder. All powdered samples were stored in airtight container at $4^{\circ} \mathrm{C}$ until used. Moreover, during field research specimens of each specie were collected, herborized and deposited for taxonomic identification in the National Herbarium, Mexico: Euphorbia prostrata (voucher: 1428601), Schinus molle L. (voucher: 1445827), Brickellia veronicaefolia (Kunth) A. Gray (voucher: 1464269) and Lepidium virginicum L. (voucher: 1218999)

\section{Preliminary Phytochemical Analysis}

Preliminary qualitative phytochemical analyses of the crude powder of the 4 plants were carried out for the detection of tannins, alkaloids, saponins, flavonoids, steroids, anthraquinone, cardiac glycosides and terpenoids following the methods reported by Parekh and Chanda (2007)

\section{Preparation of the extracts}

Plant material was, where possible, prepared in a way consistent with the traditional preparation methods (according to collected information: Decoction of the aereal part in "aguardiente", a mixture ethanol-water $2: 1$ ). $100 \mathrm{~g}$ of finely powdered aerial parts of plant samples were put into beakers containing $250 \mathrm{~mL}$ of $70 \%$ ethanol, covered with parafilm and then heated at $80^{\circ} \mathrm{C}$ in oil bath for $1 \mathrm{hr}$ with continuous stirring. The extract were filtered using Whattman filter paper (No. 1) and the solvents were removed under reduced pressure at $40{ }^{\circ} \mathrm{C}$. These crude extracts were stored in stock vials and kept at $4^{\circ} \mathrm{C}$ in refrigerator for further use.

\section{Bacterial strains}

The in vitro antibacterial activity of the extracts was tested against $S$. aureus, E. coli, Shigella spp., B. subtilis, Clavibacter spp., P. vulgaris and Salmonella spp. All these bacterial were isolated from clinical mastitis in dairy cows and obtained from the University of Guanajuato. The pathogenicity of these bacterial strains was confirmed in our laboratory.

\section{Antimicrobial Activity of the extracts using disc diffusion method}

All the bacteria were incubated at $37^{\circ} \mathrm{C}$ for 24 $\mathrm{h}$ into broth medium. The test microorganisms were diluted to a count of $108 \mathrm{CFU} / \mathrm{mL}$ and then transferred from nutrient broth to sterile Muller Hinton agar plates (CLEIDSON et al., 2007). Subsequently, filter paper discs (5 $\mathrm{mm}$ in diameter) saturated with $10 \mu \mathrm{L}$ of each hydroalcoholic extracts $(15 \mathrm{mg} / \mathrm{ml})$ were placed on surface of each inoculated 
In vitro antimicrobial...

plate with Gentamicin $(100 \mu \mathrm{g} / \mathrm{ml})$ as positive control. The diffusion of extracts was allowed for $1 \mathrm{hr}$ at room temperature on a sterile bench. The plates were then sealed with Parafilm $\mathrm{X}$ and the plates were incubated at $37^{\circ} \mathrm{C}$ for $24 \mathrm{~h}$ and $72 \mathrm{~h}$. The plates were observed for the presence of inhibition of bacterial growth and that was indicated by clear zone of inhibition of bacterial growth around the wells. Diameters of the inhibition zone were measured in millimeters ( $\mathrm{mm})$. Overall, cultured bacteria with halos equal to or greater than $7 \mathrm{~mm}$ were considered susceptible to the tested extract. Experiments were carried out in triplicates and average zone of inhibition and standard deviations were calculated. The results were expressed as mean $\pm \mathrm{SD}$.

\section{Determination of Minimum Inhibitory Concentrations}

All tested extracts exhibited antimicrobial activity at a concentration of $15 \mathrm{mg} / \mathrm{ml}$. Therefore, this concentration was manipulated to determine their minimum inhibitory concentrations (MIC) using agar well diffusion method (MOSTAFA et al., 2018). Different concentrations $10,5,2.5$, and $1.25 \mathrm{mg} / \mathrm{mL}$ were prepared by two-fold serial dilution. $1 \mathrm{ml}$ of each prepared inoculum was pipetted into sterile Petri dishes followed by the addition of molten agar and mixed well. Then, four wells were made on each plate, and $100 \mathrm{ml}$ of $10,5,2.5$, and $1.25 \mathrm{mg} / \mathrm{mL}$ of each extract was transferred to the respective wells. Plates were kept in the refrigerator for $30 \mathrm{~min}$ and then incubated at $37^{\circ} \mathrm{C}$ for $24 \mathrm{~h}$. Experiments were carried out in triplicates. The MIC was considered as the lowest concentration which inhibited the growth of the respective microorganisms. All assays were performed in triplicate. DMSO was served as a control for ethanolic extracts.

\section{RESULTS}

\section{Ethnomedicinal plants used for the prevention and treatment of bacterial infections}

It is fundamental to record and preserve the traditional knowledge on medicinal plants for future generations. In 2016 we started a project to collect
ALONSO, M. M. et al.

ethnobotanical information concerning medicinal species traditionally employed in the popular medicine in the Bajio region, Mexico.

Forty-five selected informants, including 3 traditional medicine practitioners were interviewed. The respondents confirmed that the best time to harvest the plants from the wild is before or during flowering. The ethnobotanical survey results revealed that different medicinal plants were used for recipe formulation for treating various diseases, among them Ephorbia prostrata, Schinus molle, Brickellia veronicaefolia and Lepidium virginicum were most commonly used to treat bacterial infections. The pharmacological preparations were mostly decoctions of aerial parts of vegetal species (i.e. leaves, fruit and stem), and usually the remedies are a mixture of several medicinal plants. Oral administration was the most frequently used route of administration, followed by topical applications, and for most of the remedies, the dose seemed to be a function of body size. The interviewees did not mention side effects for any of the listed plants (Table 1). The results showed that the most frequently reported diseases were bacterial infections and pain, and that the same part of the plant was used to treat different conditions. The use value for the selectec plants were generally high (Table 1). L. virginicum was the most frequently used species in the local area according to its high use value (0.96). It was mentioned by $96 \%$ of all the informants.

\section{Quantitative evaluation of phytochemicals extracted from antibacterial plants}

Preliminary phytochemical analysis revealed the presence of flavonoids and polyphenols in large quantity in the selected antimastitis plants as compared to other secondary metabolites. It is remarkable that only in L. virginicum were observed alkaloids, while saponins were present in a very small quantity, as compared to alkaloids and flavonoids, only in E. prostrata. Steroids were present in a large quantity among the selected plants. Highest terpenoids contents were found in $S$. molle followed by $B$. veronicaefolia (Table 2). 
In vitro antimicrobial...

ALONSO, M. M. et al.

Table 1. List of the plant species cited in the study: scientific name, family name, common name, part used, local medicinal uses, mode of preparation and use value (UV).

\begin{tabular}{|c|c|c|c|c|c|}
\hline Plant species & $\begin{array}{l}\text { Common } \\
\text { name }\end{array}$ & Part used & Local medicinal uses & Mode of preparation & UVs \\
\hline $\begin{array}{l}\text { Euphorbia } \\
\text { prostrata } \\
\text { (Euphorbiaceae) }\end{array}$ & Golondrina & Aerial part & $\begin{array}{l}\text { Eye Diseases } \\
\text { Dysentery } \\
\text { Diuretic } \\
\text { Antifungal } \\
\text { Antiprotozoal }\end{array}$ & $\begin{array}{l}\text { Decoction of aerial part } \\
\text { is given }\end{array}$ & 0.86 \\
\hline $\begin{array}{l}\text { Schinus molle } \\
\text { (Anacardiaceae) }\end{array}$ & Pirul & $\begin{array}{l}\text { Fruits, } \\
\text { leaves, } \\
\text { essential oils }\end{array}$ & $\begin{array}{l}\text { Antibacterial } \\
\text { Genito-urinary diseases } \\
\text { Antispasmodic } \\
\text { Healing } \\
\text { Analgesic } \\
\text { Anti-inflammatory } \\
\text { Antiviral, } \\
\text { Antifungal }\end{array}$ & $\begin{array}{l}\text { Fruits are given } \\
\text { a bath in the decoction } \\
\text { of leaves }\end{array}$ & 0.75 \\
\hline $\begin{array}{l}\text { Brickellia } \\
\text { veronicaefolia } \\
\text { (Asteraceas) }\end{array}$ & Peistó & Aerial part & $\begin{array}{l}\text { Dysentery } \\
\text { Antibacterial } \\
\text { Analgesic } \\
\text { Gastritis }\end{array}$ & $\begin{array}{l}\text { Decoction of aerial part } \\
\text { is given }\end{array}$ & 0.89 \\
\hline $\begin{array}{l}\text { Lepidium } \\
\text { virginicum } \\
\text { (Brassicaceae, } \\
\text { Cruciferae) }\end{array}$ & Lentejilla & Aerial part & $\begin{array}{l}\text { Dysentery } \\
\text { Antibacterial }\end{array}$ & $\begin{array}{l}\text { Decoction of aerial part } \\
\text { is given }\end{array}$ & 0.96 \\
\hline
\end{tabular}

Table 2. Phytochemical screening of the selected anti-bacterial plants.

\begin{tabular}{llllll}
\hline \multirow{2}{*}{$\begin{array}{l}\text { Phytochemical } \\
\text { constituents }\end{array}$} & Tests & E. prostrata & $\begin{array}{l}\text { S. } \\
\text { molle }\end{array}$ & B. veronicaefolia & L. virginicum \\
\cline { 3 - 6 } & Mayer & - & - & - & ++ \\
\multirow{2}{*}{ Alkaloids } & Wagner & - & - & - & ++ \\
& Dragendroff & - & - & - & ++ \\
& Hagers & - & - & - & +++ \\
\hline \multirow{2}{*}{ Flavonoids } & Shinoda & + & ++ & ++ & - \\
& Basic test & + & ++ & ++ & ++ \\
Tannins/Phenol & Ferric chloride & + & ++ & +++ & - \\
Saponins & Foam test & + & - & - & - \\
Anthraquinone & Borntrager & - & - & - & ++ \\
Cardiac glycosides & Keller-Kiliani & + & - & - & ++ \\
\hline \multirow{2}{*}{ Steroids } & Liebermann- & ++ & + & + & - \\
& Burchard & ++ & + & + & - \\
\hline \multirow{2}{*}{ Terpenoids } & Salkowski & ++ & ++ & ++ & ++ \\
\hline
\end{tabular}

$+++=$ Copiously present, $++=$ Moderately present, $+=$ Slightly present, $-=$ Absent. 
In vitro antimicrobial...

ALONSO, M. M. et al.

Table 3. Bacterial zone of inhibition $(\mathrm{mm})$ by extracts of selected anti-mastitis plants at $15 \mathrm{mg} / \mathrm{ml}$.

\begin{tabular}{|c|c|c|c|c|c|c|c|c|c|}
\hline \multirow{3}{*}{ Microorganism } & \multicolumn{9}{|c|}{ Diameter of inhibition zone at different concentration levels (mm) } \\
\hline & \multicolumn{2}{|c|}{ E. prostrata } & \multicolumn{2}{|c|}{ S. molle } & \multicolumn{2}{|c|}{ B. veronicaefolia } & \multicolumn{2}{|c|}{ L. virginicum } & \multirow{2}{*}{$\begin{array}{l}\text { Gentamicin } \\
24 \mathrm{~h}\end{array}$} \\
\hline & $24 \mathrm{~h}$ & $72 \mathrm{~h}$ & $24 \mathrm{~h}$ & $72 \mathrm{~h}$ & $24 \mathrm{~h}$ & $72 \mathrm{~h}$ & $24 \mathrm{~h}$ & $72 \mathrm{~h}$ & \\
\hline S. aureus & $9.8 \pm 1.9$ & $10.4 \pm 1.3$ & na & na & $8.0 \pm 0.2$ & $8.5 \pm 0.2$ & $8.5 \pm 0.9$ & $9.2 \pm 0.7$ & 17 \\
\hline E. coli & na & na & na & na & na & na & $7.9 \pm 0.1$ & $11.4 \pm 0.5$ & 25 \\
\hline Shigella spp. & na & na & $7.9 \pm 0.1$ & $12.2 \pm 1.5$ & $8.7 \pm 0.3$ & $9.3 \pm 0.5$ & na & na & 18 \\
\hline B. subtilis & $8.4 \pm 0.5$ & $8.9 \pm 0.1$ & $8.4 \pm 0.2$ & $11.9 \pm 4.5$ & na & na & $8.6 \pm 0.6$ & $11.5 \pm 1.3$ & 16 \\
\hline $\begin{array}{l}\text { Clavibacter } \\
\text { spp. }\end{array}$ & na & na & na & na & na & na & $8.7 \pm 0.1$ & $9.6 \pm 0.6$ & 15 \\
\hline P. vulgaris & na & na & $8.9 \pm 0.2$ & $11.7 \pm 0.4$ & na & na & $8.8 \pm 0.1$ & $15.0 \pm 1.7$ & 27 \\
\hline $\begin{array}{l}\text { Salmonella } \\
\text { spp. }\end{array}$ & na & na & na & $11.5 \pm 2.4$ & $9.5 \pm 0.7$ & $10.1 \pm 0.3$ & $8.2 \pm 0.3$ & $14.7 \pm 0.3$ & 22 \\
\hline
\end{tabular}

\section{Antibacterial activities}

In the present study a total of four plant species belonging to four different families were screened for antimicrobial activity. These plants are traditionally used to treat various ailments by local inhabitants, traditional healers and herbal practitioners in Santa Rosa Range, Guanajuato. L. virginicum extracts had antimicrobial activity against test organisms (Table 3), with minimum inhibitory concentration (MIC) ranging from 6 to $10 \mathrm{mg} / \mathrm{mL}$ (Table 4), while the other three extracts had MIC range of 7 to $14 \mathrm{mg} / \mathrm{mL}$ each (Table 4).

Table 4. The Minimum Inhibitory Concentration (MIC) of plant extracts against the test microorganisms.

\begin{tabular}{lllll}
\hline \multirow{2}{*}{ Microorganism } & \multicolumn{4}{l}{ Minimum inhibitory concentration MIC $(\mathrm{mg} / \mathrm{mL})$} \\
\cline { 2 - 5 } & E. prostrata & S. molle & B. veronicaefolia & L. virginicum \\
\hline S. aureus & 10.0 & nd & 12.0 & 10.0 \\
E. coli & nd & nd & nd & 8.0 \\
Shigella spp. & nd & 20.0 & 14.0 & $\mathrm{Nd}$ \\
B. subtilis & 12.0 & 8.0 & nd & 8.0 \\
Clavibacter spp. & nd & nd & nd & 10.0 \\
P. vulgaris & nd & 9.0 & nd & 6.0 \\
Salmonella spp. & nd & 8.0 & 10.0 & 6.0 \\
\hline
\end{tabular}

\section{DISCUSSION}

The medicinal plants used in the traditional medicine may complement and offer alternatives to improve animal healthcare and hence enhanced living standards of rural communities (LANS et al., 2007). The use of phytomedicine is very common in Mexico, where medicinal herbal repertoire is one of the world's most diverse. Despite this great tradition and the potential use that these plants could have in human health in Mexico and the growing interest of veterinarians in herbal medicine, little research had been made on the application of ethnobotanical knowledge to veterinary medicine.

In the present study the efforts were made to investigate the antimicrobial activity of those plant species which are used to treat various bacterial infectious diseases by the local population in Santa Rosa Range, Guanajuato. An ethnobotanical survey was undertaken to collect information from local communities from July to December 2016. Twentythree plants were identified as of interest for their role in traditional health practices of the community. A total of four species (E. prostrata, S. molle, B. veronicaefolia and L. virginicum) belonging to four different families were found to be the most frequently used and mentioned in the case of infectious disease, with use value between $0.75-0.96$ (Table 1).

For antimicrobial activity the hydroalcoholic extract of each plant (E. prostrata, S. molle, $B$. veronicaefolia and $L$. virginicum) was prepared and evaluated in concentration of $15 \mathrm{mg} / \mathrm{ml}$ by agar diffusion method, using Gentamicin $(100 \mu \mathrm{g} / \mathrm{ml})$ as the 
In vitro antimicrobial...

standard. The high zone of growth inhibition exhibited is in agreement with the results of the microbial growth inhibition (Table 4). It was found that although all extracts presented antimicrobial activity to at least one of the tested microorganisms, $L$. virginicum showed broad spectrum activity against 86 $\%$ of selected bacterial pathogens isolated from clinical mastitis in dairy cows. However, it did not show any activity against Shigella spp. at this concentration. In this point is important to indicate that the microorganism E.coli, which is already known to be multi-resistant to drugs, was susceptible only to the extract from $L$. virginicum. This result could correlate with the fact that this herbaceous plant is used widely in the area of study as a remedy to treat very intense gastro-intestinal infectious. This positive response of hydroalcoholic extract of $L$. virginicum on different strains of bacteria is in agreement with the findings of Avila Acevedo et al. (1993) who demostrated that the aqueous extract of this specie was effective against Escherichia coli, Salmonella typhi and Shigella boydii with a MIC $=0.220 \mathrm{mg} / \mathrm{ml}$. However, this plant has not received much attention. Significant antibacterial activity might be due to high concentration of alkaloids shown by this specie in the phytochemical analysis, which reduce the viability of gram positive and gram negative bacteria (CUSHNIE et al., 2014). Present study reveals that crude hydroalcoholic extract of $S$. molle showed similar inhibition zones against Shigella spp., B. subtilis and $P$. vulgaris. This result is according to studies conducted by Martins et al. (2014) the essential oil from this specie showed antimicrobial activity against gram positive, gram negative pathogenic bacteria and food spoilage fungi. The inhibitory activity of this plant could be due to presence of polyphenols and flavonoids in large quantity, which have been widely reported as antimicrobial agents (COPPO; MARCHESE, 2014). On the other hand, the crude extract of $B$. veronicaefolia showed sharp inhibition zones against $S$. aureus and Salmonella spp., as well as Shigella spp. $B$. veronicaefolia is available commercially in herbal stores and is presently and commonly used by diabetics as a cheaper alternative to insulin. The hypoglycaemic effect was confirmed and a bioactive compound has been isolated (ANDRADE-CETTO; HEINRICH, 2005). Finally, $E$. prostrata only showed activity against $\mathrm{S}$. aureus and B. subtilis.

The results indicated that as for as antimicrobial activity is concerned, the ethanolic
ALONSO, M. M. et al.

extract of the aerial part of $L$. virginicum exhibited the strongest antimicrobial activity as compared to $E$. prostrata, S. molle and B. veronicaefolia, though all these plants are used for the same purposes in different localities. The Gentamicin was used as the reference antibiotic in the present study, and it have showed the antimicrobial activity against all the test microorganisms used in the present research.

The present study shows that the plants used in the traditional system of medicine in Santa Rosa Range, Guanajuato, possess antimicrobial activity which in the extracted form can be utilized successfully to treat infectious diseases as bovine mastitis. This ethnobotanical information offer a great reservoir for the discovery of antimicrobial drugs.

The results obtained in the present research have very promising antimicrobial activities against bacteria causing bovine mastitis, therefore supporting the ethnomedical uses of these species. Our study, which is still at a preliminary stage, justify the use of these medicinal plants to develop new veterinary drugs, with low cost and without side effects, avoiding the use of antibiotics. This will be a great contribution in improving animal's health. Furthermore, it is desirable to make in depth studies of these plants for the isolation and characterization of antimicrobial compounds responsible for some of the activity we have observed, prior to further bioassays. It is important to indicate that studies on in vivo trials should also be carried out to validate the present results.

\section{ACKNOWLEDGEMENTS}

The authors acknowledge the financial support provided by CONACYT and SIP-IPN. We are also grateful to Julio César Enrique López Salazar who voluntarily agreed share his rich knowledge on medicinal plants. 
RESUMO: O presente estudo teve como objetivo investigar a eficácia de plantas antibacterianas tradicionalmente usadas (Euphorbia prostrata, Schinus molle, Brickellia veronicaefolia e Lepidium virginicum) na cordilheira Santa Rosa, em Guanajuato, contra os principais patógenos causadores de mastite. As plantas selecionadas foram rastreadas fitoquimicamente quanto a alcalóides, flavonóides, polifenóis, saponinas, antraquinona, glicosídeos cardíacos, esteróides e terpenóides. Além disso, para atingir o objetivo principal da presente pesquisa, extratos de plantas selecionadas foram testados quanto à atividade antibacteriana in vitro contra Staphylococcus aureus, Escherichia coli, Shigella spp., Bacillus subtilis, Clavibacter spp., Proteus vulgaris e Salmonella spp. Todas essas bactérias foram isoladas de mastite clínica em vacas leiteiras. Os resultados indicaram que o extrato etanólico da parte aérea de L. virginicum exibia a atividade antimicrobiana mais forte e poderia ser uma espécie potencial candidata ao desenvolvimento de novos medicamentos veterinários com baixo custo e menos efeitos colaterais.

PALAVRAS-CHAVE: Antibiótico. Etnomedicina. Mastite bovina. Doença infecciosa.

\section{REFERENCES}

AVILA ACEVEDO, J. G.; J. L. MUÑOZ LÓPEZ \& G. MARTÍNEZ CORTÉS (1993) In Vitro Antimicrobial Activity of Various Plant Extracts Used by Purépecha against some Enterobacteriaceae. International Journal of Pharmacognosy, v. 31, n. 1, p. 61-64.

ANDRADE-CETTO, A.; HEINRICH, M. Mexican plants with hypoglycaemic effect used in the treatment of diabetes. Journal of Ethnopharmacology, v. 99, n. 3, p. 325-348, 2005.

https://doi.org/10.1016/j.jep.2005.04.019

BASKARAN, S. A.; KAZMER, G. W.; HINCKLEY, L.; ANDREW, S. M.; VENKITANARAYANAN, K. Antibacterial effect of plant-derived antimicrobials on major bacterial mastitis pathogens in vitro. Journal of Dairy Science, v. 92, n. 4, p. 1423-1429, 2009. https://doi.org/10.3168/jds.2008-1384

BIESKI, I.G.C.; LEONTI, M.; ARNASON, J.T.; FERRIER, J.; RAPINSKI, M.; VIOLANTE, I.M.P.; BALOGUN, S.O.; PEREIRA, J.F.C.A.; FIGUEIREDO, R.C.F.; LOPES, C.R.A.S.; SILVA, D.R.; PACINI, A.; ALBUQUERQUE, U.P.; MARTINS, D.T.O. Ethnobotanical study of medicinal plants by population of Valley of Juruena Region, Legal Amazon, Mato Grosso, Brazil. Journal of Ethnopharmacology, v. 173, n. 15, p. 383-423, 2015. https://doi.org/10.1016/j.jep.2015.07.025

CLEIDSON, V.; DE SOUZA, S. M.; SMÂNIA, E. F. A.; SMÂNIA, JR, A. Screening methods to determine antibacterial activity of natural products. Brazilian Journal of Microbiology, v. 38, n. 2, p. 369-380, 2007. https://doi.org/10.1590/S1517-83822007000200034

COPPO, E.; MARCHESE, A. Antibacterial activity of polyphenols. Current Pharmaceutical Biotechnology, v. 15, n. 5, p. 380-390, 2014. https://doi.org/10.2174/138920101504140825121142

CUSHNIE, T. P. T.; CUSHNIE, B.; LAMB, A. J. Review alkaloids: an overview of their antibacterial, antibiotic-enhancing and antivirulence activities. International Journal of Antimicrobial Agents, v. 44, n. 5, p. 377-386, 2014. https://doi.org/10.1016/j.ijantimicag.2014.06.001

FARHA, M. A.; BROWN, E. D. Strategies for target identification of antimicrobial natural products. Natural Product Reports, v. 33, n. 5, p. 668-680, 2016. https://doi.org/10.1039/C5NP00127G

GOMES, F.; HENRIQUES, M. Control of bovine mastitis: Old and recent therapeutic approaches. Current Microbiology, v. 72, n. 4, p. 377-382, 2016. https://doi.org/10.1007/s00284-015-0958-8

LANS, C; TURNER, N; KHAN, T; BRAUER, G; BOEPPLE, W. Ethnoveterinary medicines used for ruminants in British Columbia, Canada. Journal of Ethnobiology and Ethnomedicine, v. 3, n. 11, 2007. https://doi.org/10.1186/1746-4269-3-11 
LEBLANC, S. J.; LISSEMORE, K. D.; KELTON, D. F.; DUFFIELD, T. F.; LESLIE, K. E. Major advances in disease prevention in dairy cattle. Journal of Dairy Science, v. 89, n. 4, p. 1267-1279, 2006.

https://doi.org/10.3168/jds.S0022-0302(06)72195-6

MARTINS, M. R.; ARANTES, S.; CANDEIAS, F.; TINOCO, M. T.; CRUZ-MORAIS, J. Antioxidant, antimicrobial and toxicological properties of Schinus molle L. essential oils. Journal of Ethnopharmacology, v. 151, n. 1, p. 485-492, 2014. https://doi.org/10.1016/j.jep.2013.10.063

MOSTAFA, A. A.; AL-ASKAR, A. A.; ALMAARY, K. S.; DAWOUD, T. M.; SHOLKAMY, E. N.; BAKRI, M. M. Antimicrobial activity of some plant extracts against bacterial strains causing food poisoning diseases.

Saudi J. Biol. Sci., v. 25, n. 2, p. 361-366, 2018. https://doi.org/10.1016/j.sjbs.2017.02.004

MUBARACK, H. M.; DOSS, A.; RANGASAMY, D.; VENKATASWA, R. Activity of some selected medicinal plant extracts against bovine mastitis pathogens. Journal of Animal and Veterinary Advances, v. 10, n. 6, p. 738-741, 2011. https://doi.org/10.3923/javaa.2011.738.741

PAREKH, J.; CHANDA, S. V. In vitro antimicrobial activity and phytochemical analysis of some Indian medicinal plants. Turkish Journal of Biology, v. 31, p. 53-58, 2007.

PIETERSE, R.; SVETDSLAV, T. D.; DICKS, L. M. T. Mode of action and in vitro susceptibility of mastitis pathogens to macedocin ST91KM and preparation of a teat seal containing the bacteriocin. Brazilian Journal of Microbiology, v. 41, n. 1, p. 133-145, 2010. https://doi.org/10.1590/S1517-83822010000100020

PINEDO, P.; KARREMAN, H.; BOTHE, H.; VELEZ, J.; RISCO, C. Efficacy of a botanical preparation for the intramammary treatment of clinical mastitis on an organic dairy farm. The Canadian Veterinary Journal, v. 54, n. 5, p. 479-484, 2013.

SAINI, V.; MCCLURE, J. T.; LÉGER, D.; KEEFE, G. P.; SCHOLL, D. T.; MORCK, D. W.; BARKEMA, H. W. Antimicrobial resistance profiles of common mastitis pathogens on Canadian dairy farms. Journal of Dairy Science, v. 95, n. 8, p. 4319-4332, 2012. https://doi.org/10.3168/jds.2012-5373

SHARMA, A.; FLORES-VALLEJO, R. C.; CARDOSO-TAKETA, A.; VILLARREAL, M. L. Antibacterial activities of medicinal plants used in Mexican traditional medicine. Journal of Ethnopharmacology, v. 208, p. 264-329, 2017. https://doi.org/10.1016/j.jep.2016.04.045

WELLENBERG, G. J.; VAN DER POEL, W. H. M.; VAN OIRSCHOT, J. T. Viral infections and bovine mastitis: a review. Veterinary Microbiology, v. 88, n. 1, p. 27-45, 2002. https://doi.org/10.1016/S03781135(02)00098-6

ZAFALON, L. F.; NADER FILHO, A.; OLIVEIRA, J. V.; RESENDE, F. D. Subclinical mastitis caused by Staphylococcus aureus: cost benefit analysis of antibiotic therapy in lactating cows. Arquivo Brasileiro de Medicina Veterinária e Zootecnia, v. 59, n. 3, p. 577-585, 2007. 